\title{
APPLICATION OF FUNCTIONAL ANALYTIC PSYCHOTHERAPY: CLINICAL ANALYSIS OF A PATIENT WITH DEPRESSIVE DISORDER
}

\author{
Rafael Ferro García, Luis Valero Aguayo, M. Carmen Vives Montero
}

\begin{abstract}
APLICACION DE LA PSICOTERAPIA ANALITICA FUNCIONAL. UN ANALISIS CLINICO DE UN TRASTORNO DEPRESIVO
\end{abstract}

\begin{abstract}
La Psicoterapia Analítica Funcional está basada en los principios del conductismo radical y pone el énfasis en las contingencias que ocurren dentro de la sesión terapéutica, en el contexto terapéutico, en la equivalencia funcional, en el reforzamiento natural y en el moldeamiento. Por otro lado, la depresión es un tema complejo y de difícil solución terapéutica que requiere de una explicación y una intervención pluricausal. Se presenta el análisis clínico de un caso que presentaba un trastorno depresivo y su tratamiento a través de la aplicación de esta psicoterapia. Se describen las distintas fases de la intervención con ejemplos de la relación terapéutica, y el mantenimiento de los resultados durante un periodo de un año y tres meses.

Palabras Clave: DEPRESION, ANALISIS FUNCIONAL, PSICOTERAPIA ANALITICA FUNCIONAL.

Functional Analytic Psychotherapy is based on principles of radical behaviorism, and emphasizes the contingencies that occur during a therapeutic session, the therapeutic context, functional equivalence, natural reinforcement, and shaping. Depression is a complex problem with multiple causes; the treatment of depression must therefore be approached from different angles. A clinical analysis of a patient with a depressive disorder and its treatment with this type of psychotherapy is presented. The different phases of intervention are described, with examples of the therapeutic relationship. The results were maintained for a period of one year and three months.

Key words: DEPRESSION, FUNCTIONAL ANALYSIS, FUNCTIONAL ANALYTIC PSYCHOTHERAPY.
\end{abstract}

Functional Analytic Psychotherapy (FAP) (Kohlenberg and Tsai, 1991), along with Acceptance and Commitment Therapy (ACT) (Hayes, Strosahl, and Wilson, 1999), are two approaches to therapy based on the principles of radical behaviorism and on findings regarding functional generalization, functional analysis of language, and equivalence relations. For further information in Spanish about the implementation of FAP and ACT, two pioneering texts published by Pérez Álvarez are highly recommended: "Tratamientos Psicológicos" (1996a) and "La Psicoterapia desde un punto de vista conductista" (1996b). Functional analytic psychotherapy places emphasis on the contingencies that arise during the session, within the therapeutic context, in functional equivalence, natural reinforcement and shaping (Kohlenberg and Tsai, 1991, 1995). This approach places major importance on what the client says and does in the presence of the therapist, rather than on homework, events that take place in the family setting, or the thoughts the client may have during other parts of his or her daily life. These manifestations are termed clinically relevant behaviors (CRB), and are classified into three types that the therapist should learn to identify as therapeutic goals (Hayes, Kohlenberg and Melancon, 1989; Kohlenberg, Hayes and Tsai, 1993; Kohlenberg and Tsai, 1991, 1994a, 1994b, 1995). The first category of CRB (CRB1) are actual instances of the client's problems during the session, and which the therapist should try to diminish in frequency. Normally, these behaviors are under the control of aversive stimuli and often consist of avoidance behaviors. These problems may involve thoughts, perceptions, feelings, visions or memories that occur in the course of the session. The second category (CRB2) are improvements shown by the client during the session. In the early phases of treatment these behaviors are absent or are manifested only weakly, but as therapy progresses they should become more frequent. 
Behaviors considered (CRB3) are interpretations by the client of his or her own behavior and its causes. They involve observations and descriptions of the client's own behavior and the reinforcing, discriminative and eliciting stimuli associated with these behaviors. Kohlenberg and Tsai (1991) refer to CRB3 as "clients' talking about their own behavior and what seems to cause it," thereby expressing appropriate cause-effect relationships and describing functional relationships that have established the problem.

In addition, FAP considers the therapist's in-session behavior by proposing therapeutic rules in the form of guidelines or methods to help evoke or reinforce the client's behaviors, and help the client to identify them to the therapist and interpret them. Five rules have been developed for therapists (Kohlenberg, Hayes and Tsai, 1993; Kohlenberg and Tsai, 1991, 1994a, 1995). Rule 1 advises the therapist to develop a repertoire for observing possible CRB during the session. Rule 2 proposes building a therapeutic environment that is evocative of CRB. Rule 3 encourages therapists to arrange for positive reinforcement for CRB2. Rule 4 recommends developing a repertoire for observing the potential reinforcing properties of the therapist's behavior that are contingent upon the client's CRB. Rule 5 urges the therapist to develop a repertoire for describing the functional relationships between controlling variables and the client's CRB. This rule has to do with both the patient's interpretations and modeling by the therapist.

Functional analytic psychotherapy has been used for depressive disorders (Dougher and Hackbert, 1994; Kohlenberg and Tsai, 1994a), personality disorders (Koerner, Kohlenberg and Parker; 1996), patients subjected to sexual abuse (Kohlenberg and Tsai, 1998), patients who avoided intimate relationships (Cordova and Koerner, 1993), persons suffering from anxiety (Kohlenberg and Tsai, 1995), and, together with acceptance and commitment therapy, in a case of exhibitionism (Paul, Marx, and Orsillo, 1999).

Psychotherapy for depression is complex. As noted by Biglan (1991), depression does not have a single identifiable cause, hence the explanation for depression must be based on multiple causes. We agree with Pérez Alvarez (1996b) that functional behavioral analysis offers a multicausal, contextual and dynamic explanation of psychological functioning, specifically for depression. One of the earliest analyses of depression from a behaviorist viewpoint was published by Ferster in 1973 (Dougher and Hackbert, 1994; Pérez Alvarez, 1996b), although it was not until the 1990s that current analyses of depression from a behaviorist theoretical perspective began to appear (Biglan, 1991; Bolling, Kohlenberg and Parker, 1999; Dougher and Hackbert, 1994; Kohlenberg and Tsai, 1994a; Pérez Alvarez, 1996b). These studies provided complex functional analyses of depressive behavior with a view to its consequential and respondent functions, establishing operations and verbal processes.

Here we offer a detailed clinical analysis of a patient with depressive disorder who was treated with FAP. For each phase of therapy we provide examples of the CRB identified and therapeutic rules that were used. To our knowledge, this is the first attempt to explicitly associate the rules of FAP with specific CRB in a report of an actual clinical case.

\section{METHOD}

\section{Subject}

Ana was 36 years old when she first came to the center. She was the youngest of three children, and held a civil service job. She had requested a transfer to a post in a different location 4 months before her first visit to the center, and had moved in with her family. She had been in an intimate relationship for 8 years, although she had not cohabited with her partner. One month before she sought psychological help, her partner had told her he no longer loved her and that their relationship would have to end. Since then she had felt very bad. She lost her appetite and lost $9 \mathrm{~kg}$, as a result of which she was markedly 
underweight. She never went out and spent all her time in her room lying in bed or watching TV. She was apathetic and did not feel like doing anything. It was hard for her to get a good night's sleep. She felt guilty for moving to another town and leaving her former boyfriend behind. She admitted that during the previous 2 years their relationship had not worked well and that they often argued.

When she came to the center she could not accept what had happened to her. She felt that her life had lost its meaning because none of her goals, such as having a family and children, could be realized. She was unable to accept her age and felt too old to begin a new life and achieve her goals. She had nobody to spend her leisure time with because she has lost all her friends. She had no hobbies because all her leisure time activities had been shared with her former partner. She took anxiolytics when she felt anxious. During the initial sessions she had crying episodes and made statements such as, "I can't take any more. I have nothing to look forward to. What am I going to do with is my life? I wanted to start a family and have children. I don't care about things the way I did before-it's all the same to me now. How could he do this to me? I don't deserve what he did to me. I trusted him. What's going to happen to me now? I don't feel like doing anything. He hurt me so badly. I don't feel like living any more. My life has no meaning." The client fulfilled the DSM-IV criteria for a diagnosis of major depressive disorder (APA, 1994). In other words, she presented a single episode of depression with the following symptoms: depressed mood most of the day, marked decrease in interest in activities, significant weight loss, insomnia, fatigue, and feelings of uselessness and guilt.

\section{Procedure}

It was felt that the client would benefit from acceptance-based therapy, since part of her problem was that she had trouble accepting herself or the life situation she was in. It was decided to try FAP (Kohlenberg and Tsai, 1991).

The case will be described below in accordance with the concepts proposed by Cordova and Koerner (1993). That is, instead of providing data, we provide a description of the client-therapist relationship during treatment. The transcripts of dialogs reproduced here are based on summaries written by the therapist after each session, as the client declined to allow the sessions to be audiotaped.

Therapy lasted approximately 2 years and consisted of a total of 48 sessions and follow-up telephone interview 1 year and 3 months after the final session in the therapist's office. The first three sessions were used to obtain information for functional analysis of the problem, and to set goal behaviors. Both of these processes are summarized below.

\section{Functional analysis}

The client's rate of social behaviors was very low: she did not leave her room or speak to members of her family, had no social relationships, and avoided seeing her old friends. This was probably a consequence of extinction and punishment contingencies in relation with her former boyfriend and other persons. Her situation was such that she did not receive positive consequences; in other words her rate of reinforcement was low. In addition, when she felt sad and complained of feeling bad, her family tried to help her by encouraging her to go out, to eat more, to cheer up, and to stop crying. These attempts, however, led her to stay in her room and spend more time crying, and to get upset with her family. Her family thus reinforced her sadness and distressed behavior. Thinking she was lonely and that her goals for the future had vanished made her feel sad and spend time crying (i.e., they evoked respondent functions). She avoided situations which might lead to contact with other persons, because they acted as discriminative stimuli for punishment or extinction contingencies Her boyfriend leaving her functioned as an establishing operation (Michael, 1993; Sundberg, 1993), that is, as an event that affected the client by altering the effectiveness of other events as reinforcers. Things that previously had been reinforcing, such 
as going out, eating, talking with others or going to the movies, ceased to serve this function. In addition the frequency of behaviors that were reinforced by these events was also reduced. As a result her verbal behavior was maladaptive, and the tacts she emitted regarding the cause of her problem were inappropriate. For example, she blamed the fact that the relationship had ended on her former boyfriend's family. In addition, she expressed disguised mands and impure tacts (Skinner, 1957): she complained about her situation, about how bad she felt, about how much she was suffering, and about how badly others treated her. These complaints were termed distressed behavior by Biglan (1991), who maintained that they were often maintained by negative reinforcement since with these behaviors, patients tend to avoid the aversive consequences of contact with others. Cultural beliefs such as the concept of happiness and well-being also influenced the patient's problem, as she felt that her situation was incompatible with being happy. A final observation was that the patient responded to words as though they were actions (through stimulus equivalence). For example, during one session she responded as though her exboyfriend had actually telephoned: "If he calls me to ask me to still be friends with him, I won't go to the phone. No, no! I'm not taking the phone! [Insults] I don't want to be his friend!"

\section{Clinically relevant behaviors}

The CRB1 identified were:

1. Not accepting her situation. Not accepting that her boyfriend had left her, and all related behaviors such as refusing to talk about him and insulting him during sessions. Not accepting that her plans to form a family and have children no longer made sense.

2. Social isolation and avoidance of relations with others. Being alone, not having anyone to spend her free time with, losing all her social relationships. Being unwilling to talk about looking for alternatives. Being afraid that if she began a new relationship, it would end like the one with her exboyfriend. Being socially aggressive (fighting, arguing, insulting, breaking things, etc.).

3. Apathy. Not caring about anything. Not feeling like eating, listening to music, going out, shopping for clothes or reading magazines, but spending her time lying in bed or watching TV. Losing weight. Not having any hobbies. Not talking about other things besides her problems.

4. Poor appearance and self-concept. Complaining about her appearance, not wearing snug-fitting skirts, pants or a bathing suit. Complaining about her age, not wanting to state her age, seeing herself as older than she was.

5. Avoiding bad feelings. Getting upset when she felt anxious or sad, not going to the doctor's or dentist's to avoid physical pain. Avoiding talking about things that made her unhappy. Avoiding feeling anxious. Smoking to calm down. Taking anxiolytics to keep from feeling anxious.

6. Not explaining clearly what had happened, and about her own and others' behavior. Blaming others for her own problems. Not admitting her role in the events, not knowing why things had happened that way.

7. Complaining about what had happened, about her life, about the things others did, and about how others treated her. Criticizing others, not understanding other persons' preferences.

The CRB2 chosen for intervention were: 
1. Accepting what had happened. Talking calmly about the past, her relationship, and her exboyfriend. Describing her own responsibility for what had happened. Not crying, getting upset, or insulting her ex-boyfriend when she talked about the breakup.

2. Holding on to positive social relationships. Going out and meeting people. Accepting that others are different. Not fighting or being aggressive. Understanding others. Maintaining a cordial, pleasant relationship with the therapist.

3. Having plans to get on with her life. Getting involved in new activities, meeting more people, calling old friends, etc. Studying to apply for a job promotion. Expanding her range of activities. Talking about different subjects during sessions.

4. Accepting herself as she really was, accepting her age and appearance, not worrying about finding a partner before she got too old. Not worrying about starting a family and having children soon.

5. Establishing functional relationships (CRB3) appropriately. Explaining what had happened in her life, her past, how she could get over the situation, etc.

\section{INTERVENTION}

\section{(A) Initial phase}

\section{Sessions 1 to 10}

This phase comprised the first six months of treatment from sessions 1 to 19 . During Sessions 1 , $\underline{2}$, and 3 , in the first 3 weeks of therapy, the client's problems were evaluated and a functional analysis was carried out. During this period her rate of CRB1 was high. She cried frequently and fidgeted in her seat, dropped things and smoked frequently (approximately 5 to 10 cigarettes per session). She complained constantly, with frequent exclamations such as: "I can't take any more!", "I don't deserve this!" or "What am I going to do with my life?" She stated that she had had problems with the persons around her. For example, during her ex-boyfriend's last phone call, when he told her their relationship would have to end and that he wanted them to remain friends, she got so angry she broke the phone when she slammed down the receiver without saying good-bye. As she described this event she raised her voice, insulted her ex-boyfriend, and responded as if he were actually on the phone at that time. She responded literally to language as though it represented actions (for a more detailed explanation, see Ferro and Valero, 1998; and Hayes and Wilson, 1993, among others). During the final summer of their relationship she argued with her family and her boyfriend, and insulted him in public on several occasions.

During Sessions 4 to 10 , from the fourth week to the end of the third month of therapy, complaining continued to by the most frequent CRB1. For example, she often said she didn't feel like doing anything, didn't know why life was so hard, didn't understand why life had treated her so badly, and was very hurt that her boyfriend had not phoned. The therapist did not respond to these complaints since his intention was to extinguish them (Rule 3). Some of the client's explanations for what had happened to her became more appropriate (CRB3). For example, she sustained that on weekends she felt very bad and that during the week she felt better while she was at work, but felt bad again during the evenings. She said she felt guilty when she reacted badly to something or was rude to someone. She noted that she avoided arguing with her family (CRB2). In response to these comments the therapist used the description of how badly she felt and how hard she was trying to get over it, as ways to reinforce these behaviors ("You must really love your family. You're having a really bad time now with all this, and are 
really trying hard to get over it"). The rules she expressed about the breakup (CRB3) were still inappropriate, she failed to admit her own responsibility for the breakup, and blamed her ex-boyfriend's family. When these explanations appeared, the therapist used shaping (Rule 5) with questions such as: "Why do you think that? Do you really think X left you because of his family? If that's the case, why didn't he leave you earlier? What happened during those last few years?" Although the client was reluctant to answer these questions, she began to express more appropriate rules: "He didn't love me. I didn't realize before because I was blind" (CRB2 and CRB3). Contingent upon these positive rules, the therapist used the description of her emotional distress as a reinforcer (Rule 3). This was effective, as it increased the frequency with which she talked about negative aspects of the relationship (Rule 4).

In Session 7 CRB2 began to become more frequent. The client said she was thinking of enrolling for driving classes and made some positive comments about her job, although CRB1 were still frequent. For example, she complained about her life and that everyone had abandoned her. She commented that when her colleagues at work talked about their families and children, she evaded the situation. She mentioned several cases of suicide that others had told her about. When she mentioned the suicides, the therapist asked "Are you going to commit suicide?" and later noted "Ifyou want to kill yourself, there's nothing I can do to stop you. But it would make me feel very bad, " using an expression of his own feelings as a way to evoke CRB (Kohlenberg and Tsai, 1991). After this the client never mentioned suicide again (Rule 4). Another example of Rules 3 and 4 was when the patient showed the therapist a photograph taken of her a taken few years previously, to show him how much better she looked before. In the picture she weighed more and looked better, and she asked the therapist, "See how bad I look now?" (This was a CRB1 that functioned as a disguised mand intended to prove how bad she looked and felt at the time of the session.) In this situation the therapist replied "Oh yeah" and left the picture lying on the desk (with the intention of extinguishing these mands). During subsequent sessions the client did not repeat this type of behavior.

During these sessions, CRB1 were frequent. The patient complained, expressed confusion about her feelings, was unable to express how she felt or to explain why she felt bad. Crying episodes continued. She used culturally-determined rules to face her problem. For example, she commented, "It's better to laugh to keep from crying," and "Time heals all wounds." She rejected her appearance. Her explanations about what was happening to her and what she should do were inappropriate: "This is what I get for being a good person. If I'd been tougher... ." However, more positive CRB3 also appeared: "I should stop brooding and get over my depression. " Some of the dialogs during this initial phase were revealing, as in these examples of Rule 5:

Therapist (T): How would you define happiness?

Client (C): Not having any problems in life. (Cultural influences on happiness)

$\mathrm{T}$ : Do you think happiness is not having any problems?

C: [The client remains silent.]

T: Do you think I don't have any problems? With my job, or with my family, for example?

C: I guess so. But you know how to deal with your problems.

T: How would you define an intimate relationship?

C: Until this happened, I thought that an intimate relationship had to last your whole life, like my parents' relationship. (This ply rule and its pliance made it hard for the client to accept the breakup and insensitive to its consequences.) (For more information on pliance see Hayes, Zettle and Rosenfarb, 1989 and Zettle and Young, 1987).

T: What about now?

C: I don't think that anymore. 
She also mentioned she had been invited to a wedding, but was reluctant to go.

T: Why aren't you going to the wedding?

$\mathrm{C}$ : Because of the people. I don't trust the people (CRB1).

T: Do you trust me? (This question compared what happened in-session with what happened outside the session. According to Kohlenberg and Tsai, 1991, p. 60, this is a way to evoke CRB.) C: Yeah, I do.

$\mathrm{T}$ : What makes me different from other people?

C: You seem like a good person.

T: Can't there be other good persons in your life too?

C: I wish.

$\mathrm{T}$ : At the wedding you might make new acquaintances or run into someone you know.

C: So what?

T: It might be fun.

C: I doubt it. (The client was unwilling to consider the possibility, and the therapist did not take the subject any further because he felt he might be reinforcing negative rules. This is an example of Rule 4).

During the following session the client remarked that she had gone to the wedding, so the shaping during the previous session had been effective (Rule 4). After that, a change was apparent. She noted that she had run into a friend and they had arranged to meet and go out. Her appearance had improved. The therapist commented that she looked better and that he liked how she looked (using his own feelings as a natural reinforcer; Kohlenberg and Tsai, 1991). She said she had gone to the hairdresser's and thought she had gained some weight, or at least she was trying to eat better. The therapist said he was sure she was feeling better. In reply, she said, "I've calmed down some." Later, she remarked "What I need to do is meet people" (CRB3). Recognizing that progress has been made is a sign that identifies CRB (Kohlenberg and Tsai, 1995).

Sessions 11 to 19 During this period (from the beginning of the fourth month until the end of the sixth month of therapy) the patient continued to talk about making plans, although she didn't act on any of them outside the sessions. Some of her plans at this time were to study for promotion to a better post, to get a driving license, and to go out shopping. She talked about these projects more frequently (Rule 4). As the Christmas season approached she admitted to feeling anxious because she had no friends to celebrate the holidays with, and she avoided making plans for New Year's Eve. She also avoided (and escaped by changing the subject) talking about her age, children and families (CRB1). During one session, when the therapist asked her about her ex-boyfriend, she became angry and responded aggressively by shouting at the therapist (Rule 2, constructing an environment that evokes CRB).

T: Have you heard from your ex-boyfriend?

C: [Shouting] Why do you have to bring that up? I'm sick and tired of everybody asking me the same thing.

T: Why are you shouting at me? I apologize if I've hit a nerve, but I didn't mean to upset you.

C: I'm sorry too.

$\mathrm{T}$ : Is that the way you communicate with people? (Compares what happens in-session with what happens outside the sessions, as a strategy to evoke CRB).

C: Sometimes. With my family.

In a subsequent session the therapist asked again whether she had heard from her ex-boyfriend, and she responded in more measured tones that she hadn't heard from him since the previous summer (CRB2). The therapist's intervention had avoided an aggressive response to the question (Rule 4). 
In a subsequent session the patient talked about her relationship, accepting what had happened and admitting to part of the responsibility. She noted that she was changing, and that she felt like enjoying herself again. She also remarked that she was trying to control her bad moods. She began to express more positive rules: "You have to take life as it comes and not fight it." When these behaviors appeared (CRB2) the therapist reinforced them (Rule 3) in consonance with his experience with this client (Rule 4). She reported that she had gone out on New Year's Eve with a female colleague from work and had enjoyed the night out. The therapist related how he had spent New Year's Eve, as a form of natural reinforcement. The client also remarked that she had gone shopping. At this point during therapy, she began to carry out the plans she had made. The therapist noted this and compared her situation earlier with the way she was feeling at that point. Using the New Year as a convenient time point, the client set some goals and commitments for herself: "I have to work to move on with things, and what happened belongs to the past." She accepted what had happened in her relationship, observing, "There's nothing I can do now about what happened to me," "I have to move on," and "I have to live my life" (CRB2). In response to a remark by the therapist, she smiled (CRB2). The therapist observed this reaction and described it, "Hey, I just caught you smiling" (Rule 1). As therapy progressed the frequency of negative CRB decreased while that of positive CRB increased.

The client still refused to accept her age. She was reluctant to talk about her age and was afraid to meet people. She stated, 'I don't want to go out with people my age because they seem old to me. I'm actually 35 (she was actually a few years older than that) but look 25. And I really feel 25 (CRB1).

In Session 17 she divulged, with no prompting by the therapist, that she had been mistreated by her ex-boyfriend. Kohlenberg and Tsai (1991, p. 60-61) note that one way to identify CRB is to be alert to subtle behaviors. This patient escaped each time the therapist tried to talk about the problems in her relationship with her ex-boyfriend. For example, "What were the last years of your relationship like? How did you get along with your boyfriend? Didn't you ever have any arguments?" The patient's response was to say she did not want to recall any of those things, or to change the subject. In this session the therapist remarked that a new patient had started therapy, and that her partner was hurting her really badly (Rule 2, constructing an environment that evokes CRB). The client spontaneously admitted that she had been abused during the relationship.

C: [Stammering] We got along really badly. I used to hit him too.

T: I don't understand. Are you talking about your relationship? You used to hit each other?

$\mathrm{C}$ : Yeah. (laughs nervously). Once he hit me in the head in public. And another time I had to go to the emergency room after he kicked me.

T: How did you manage to put up with all that?

C: I used to hit him too, but he'd hit me back harder. He used to smash things too. So did I. He broke the remote control for the TV. Once, at a party, he threw his drink in my face and walked out.

T: I don't understand. Did you love him so much that you put up with all that? You must have had a terrible time (Rule 3, reinforcement).

C: I really was miserable. I didn't feel like I was his girlfriend.

T: What rotten luck. Isn't there any other way to meet other kinds of people?

C: In my next relationship I'll be more careful so that it doesn't happen again. In my current situation I don't have anyone to go out with, and besides I don't feel like it. (The therapist stopped asking questions along this line.)

In Session 18 the client spoke again of the abuse she had received, an indication that the consequences the therapist had applied were reinforcing (Rule 4).

T: You were lucky it ended. That's not my idea of an intimate relationship. 
C: That's life. Now those memories just make me want to laugh. I was blind and couldn't see it. I only saw things through his eyes. I only want to remember when we first met, when he was a fantastic person. The client then spontaneously remarked, The most important thing for me is what a person is like on the inside, not physical attractiveness (a cultural cliché). The client further remarked, I'm tired of this situation (referring to being lonely and depressed). I know I have to get out and see other people, but I don't know how. That's life. (This comment had been made by the therapist several sessions before.)

In this session the client stopped smoking during the conversations. The therapist noticed (Rule 1) and described the situation, "Have you stopped smoking? Why?" (Rule 5). The client answered, "I'm trying to cut down." This behavior was reinforced in the same manner as had been found to be effective in one of the earliest sessions: by describing how hard the client was trying. From this session on her insession smoking decreased and eventually ceased altogether.

\section{(B) Intermediate phase}

\section{Sessions 20 to 40}

This period, comprising Sessions 20 to 40, lasted more than one year, from the beginning of month 7 to the end of month 18. In Sessions 20 to 31 (months 7 to 12), new CRB1 appeared, including problems with her relationships with others, complaints about her colleagues and job, and avoidance of talking about a conflict with one of her colleagues at work. On this latter problem, the therapist asked her repeatedly what had happened. Eventually the client responded, "I want nothing to do with her," a reaction functionally equivalent to how she reacted when her boyfriend left her. She also admitted that her bad temper persisted. She complained frequently, not about life or about the breakup, but about other persons. For example, 'I'm tired of supporting people, what I want now is for them to support me. People only look out for their own interests." New CRB2 also appeared. Through a neighbor, she met a young women who suggested she join a local cultural association. During these sessions the client was reluctant to go out, and complained about other people. The dialog transcribed below illustrates how the therapist used shaping to encourage the patient to make a greater effort to establish social relationships.

C: My situation is very difficult because I don't have any friends. (Expressing difficulties, according to Kohlenberg and Tsai, 1995, is a sign of CRB).

T: You can't complain these days, since you've just met new people.

C: I'm more independent, and I don't go running after people. If you open up to people, they can hurt you. (Reluctance, a CRB1).

T: You opened up to me. Have I hurt you? (comparison of the therapeutic relationship with the relationship with others)

C: That's different.

T: Why?

$\mathrm{C}$ : Because this is your job.

T: Do you think that if it weren't my job, then I'd hurt you?

C: No. I've hurt myself more than he did. (referring to her ex-boyfriend).

At the next session she remarked that she had gone to the cultural association meeting with her new acquaintance, a sign that the shaping had been effective (Rule 4). In subsequent sessions she noted that she had met another women, who was, in her opinion, "crazy." She stated, "I was really disappointed when I got back. But then I thought it was funny. It was toward the end of the evening, and the only thing this girl wanted to do was drink. She was really rude to me." She seemed to deal well with this disappointing outcome. 
Another CRB1 appeared in relation to her job. She noted that the felt she might be fired but was reluctant to explain why. She admitted skipping a meeting to avoid feeling anxious. With shaping by the therapist, she explained that she might be fired because she was too thin (an irrational idea because she had a permanent civil service job). She then changed the subject and said, "People have asked me 'How's your boyfriend? When are you getting married?' and it's given me a lump in my throat." The therapist compared her situation at work with her relationship with her boyfriend, asking her, "Does your job make you feel bad the way your relationship with your boyfriend does?" to establish equivalence between the two situations. The therapist felt she was avoiding talking about her job, so this was tried on the basis of Rule 2, which proposes creating an environment that evokes CRB.

During the subsequent months her circle of social acquaintances broadened. In one session she described how she'd failed to turn up as arranged to meet one of her friends, and noted that her friend might be upset with her. She began to cry and said, "I feel out of place in the world" (according to Kohlenberg and Tsai, 1995, talking about difficult feelings is a sign of CRB), instead of saying she felt guilty for what she had done. This reaction was probably a mand. The therapist moved the box of tissues closer to her and waited for her to stop crying (Extinction, Rule 3), and then asked, "Why didn't you go to meet her as planned? Weren't you ashamed of yourself to just stand her up that way? Did you apologize to her?" (Rule 5).

A relative telephoned the therapist and explained that the client's behavior toward her family was despotic, with frequent loud fights. At the next session (Session 26) the client smoked, after having abstained from smoking for eight sessions (three and a half months). She justified this by saying her colleagues at work smoked a lot (an inappropriate explanation, CRB1 and CRB3). The therapist said nothing about the phone call from her relative. He asked her how things were going at home, but she did not answer (CRB1). She mentioned feeling sad because she felt lonely at home. This was a mand, insinuating that her family ignored her). The therapist asked again about her relationship with her family, and eventually she admitted that she behaved badly toward them, explaining, "They're after me all the time, and I feel like a little girl." The therapist asked a shaping question, "Why do you think they do that? Did you tell them calmly, the way you just told me? Here you don't shout at me, and you aren 't rude to me. Why is it different with them?" The therapist compared her in-session behavior with her behavior outside the sessions to establish functional equivalence between the two settings, in an attempt to evoke CRB.

In all sessions, each time the therapist tried to analyze why the client had conflicts with her colleagues at work, she changed the subject or was reluctant to talk about it (CRB1). She was still unable to accept herself (CRB1), nor did she accept it when people told her she was looking thin. This reason kept her from attending a wedding. The therapist remarked, "You are underweight, but does that keep you from coming here?" (Rule 5, establishing comparisons again between the in-session situation and that outside the sessions). She was also too embarrassed to wear a bathing suit, and therefore avoided going to the beach with her female friend, nor was she willing to talk about this. She noted that she had gone to the wedding (the therapist reinforced this by remarking on how hard it must have been for her to make the effort), and remarked that the wedding had moved her to tears, "It could be me up there" (referring to marriage). The therapist asked her to describe what she had got out of going to the wedding (Rule 5).

At one session she started to cry as soon as she entered the room (CRB1). The therapist said nothing (Extinction, Rule 3) and she then said, "Don't worry, I'll be okay" (a mand). After a long spell of crying, she said a female friend had stopped phoning, was going out with other friends without asking her to join them, and made excuses to keep from seeing her. As she made these remarks, she began to insult and criticize her friend (CRB1). The therapist used shaping, "Do you think she used you? Is that so terrible? Hey, she's not your boyfriend. Don't you think people have the right to do what we want?" (Rule 5). Then the patient expressed rules such as: "I never do anything. When you're feeling bad you 
don't feel like doing anything." This type of complaining had been abolished in an earlier stage of therapy, but reappeared at this point.

In Session 31, after one year of treatment, there was a change in her course and she began to express more appropriate rules.

C: I've realized I have to stop being so selfish (referring to her reaction when her female friend stopped phoning her).

T: I think there's a relation between what happened and your breakup problem. When your friend left you and when your boyfriend left you, it really made you feel terrible. Do you see it that way? (The therapist explains the functional equivalence between the two situations, since they had the same effect. This was an example of Rule 5).

C: I don't know.

T: Each time something like this happens, are you going to get depressed? What if another one of your friends leaves you?

C: I'll have to carry on.

$\mathrm{T}$ : What is friendship?

C: Giving everything and not expecting anything in return.

A further example of appropriate rule-making is reflected in the exchange below:

T: What have you learned about life?

C: Locking myself away in him is the worst thing I've done in my life."

T: What about now? What's different? (The therapist urges her to compare her situation before with her current situation.)

C: I want to get out and live. I feel good. You don't need to be married or to have children to be happy. (At this time she begins to change her concept of happiness.)

She gained weight and said she was trying to eat better and felt calmer (recognizing the progress made is a CRB, according to Kohlenberg and Tsai, 1995). She contemplated new goals for herself, such as buying an apartment, taking courses in things she was interested in, and traveling.

Sessions 32 to 40 took place during months 13 to 18 of therapy. Once again during this period, complaints (CRB1) about her friends, her job, her colleagues and illnesses gradually increased. The therapist was unable to abolish complaints by ignoring them (Rule 4). The client was angry when she arrived for one session because her (female) friend had told her she always talked about the same things and that made conversations with her boring. The therapist analyzed the feelings his relation with the client evoked as a strategy to identify CRB (Kohlenberg and Tsai, 1991). Recently, the therapist had found his own relationship with the client to be boring and felt impatient for sessions to end, because the client always complained about the same things. From that moment on the therapist chose using other topics for conversation as a goal for CRB2. In subsequent sessions the client continued to complain about her job, her friends and her colleagues, and remarked that she had skipped work because of how bad she felt in the workplace (CRB1). The therapist hypothesized that she was using her depression as an excuse to skip work. She went out for walks or to go shopping or on other errands, but didn't go to work. The therapist shaped more appropriate explanations (Rule 5). The patient avoided going to work not because she was depressed, but because a long, hard day awaited her, and she avoided seeing her colleagues because they pressured her to work. Upon arriving very late for one session (CRB1) she justified the delay saying she didn't feel well and had fallen asleep. The therapist told her he couldn't see her then and postponed the session one week. During the remainder of treatment the patient was never late again for any session (Rule 4). 
At one session the patient continued to complain about the same things, and the therapist noted that she never stopped complaining that her colleagues didn't help her. He then established equivalence with arriving late for a session and how the therapist had handled the situation, and asked, "Do you think I didn't help you?" She avoided the question and replied, "I've been feeling really nervous these days; I feel really uncomfortable. What can I do?" (an adaptive mand; instead of complaining she requested help). The therapist used shaping to keep the patient from using her problems as an excuse for her difficulties with her colleagues.

In another session the client noted that she had gone to the doctor's but declined to have a blood test because of the pain (CRB1). She avoided talking about work and her colleagues. At this session she complained about illnesses. The therapist felt bored by her complaints and tried to disrupt her tendency to complain and get her to make commitments with herself:

T: Are you happy?

C: No, but what can I do? I'm trying hard to be happy. (Here she makes a commitment with herself). Everything in life (referring to friendship and love) happens when it has to happen. When I see a cloudy day (referring to an emotionally bad day) I try to cheer myself up and be more positive. I'm alone, but so what?

T: Why don't you go to work? What's up at work?

$\mathrm{C}$ : [The client remains silent.]

T: Do you realize that you're always complaining about your job, about life, and about everything? Nobody likes that. I can understand why your friend said that. (Rule 5).

During this and subsequent sessions new subjects of conversation were established, first by asking the client her opinion about leisure-time activities and later by talking about subjects initiated by the client spontaneously. At the same time the therapist tried to naturally reinforce these CRB2 (Rule 3) by saying, "Now your friend can't say that any more, about you not being able to hold a conversation about different things, because here you talk about everything." This statement compared the two settings to establish functional equivalence. The therapist also described the behavior, "Hey, where did you read that? " In accordance with Rule 4, the effects of the therapist's behavior appeared to be reinforcing because the patient talked more frequently about a variety of topics such as plants, cars or TV programs.

In the final sessions of this phase no complaining appeared (Rule 4). CRB2 became more frequent, and the patient remarked that she had made a new female friend and had met and gone out with new people who were friends of a friend. Without prompting, she brought up topics she had previously avoided, and expressed the following rules: "We all make mistakes, and my mistake was to trust that guy" (CRB2 and CRB3), "I'm not worried about finding a life partner. It's my destiny not to get married." She spoke again of future plans such as going to the dentist's and the doctor's, attending driver education classes, and buying an apartment. She applied for reassignment to a different job at work and felt glad because she had been told her chances were good. She talked about the New Year's Eve party and the person she went with. She remarked, "I'm looking forward to changing jobs so I can meet different people." The therapist described her as being a more pleasant person who talked about things he was interested in, and said he felt she was doing better. He then asked her:

T: What is the most important thing in your life?

$\mathrm{C}$ : Health and work. Life is full of obstacles you have to jump over.

$\mathrm{T}$ : What might make you feel bad now?

C: Losing my job. 


\section{C) Final phase}

\section{Sessions 40 to 48}

This period comprised Sessions 41 to 45, and lasted for 3 months, from months 19 to 21. During this phase the frequency of complaining decreased while the frequency of type 2 and 3 CRB increased. For example, the client noted, "Now that I go out with friends, I'm not going to fall apart. Life can be so nice... ." She had a conflict with her colleagues at work and analyzed what had happened with the words, "I'm more diplomatic now. Before I used to lose my temper, and if someone shouted at me, I shouted back. I created a confrontation with my colleagues, and that was the problem. Now Ijust ignore them, I just say 'Hi' and that's it." (According to Kohlenberg and Tsai, 1995, talking about progress made is a CRB2). She also established a comparison between her colleagues at her former post and her current colleagues, and concluded that the people she worked with now were different, and so was she.

In Session 44 she spoke for the first time of getting over her depression, and made commitments with herself: "I want to get on with my life and meet people" (CRB2). She got in touch with a female friend she had known before and arranged to meet and do something together. She noted that she no longer had problems with her colleagues at work because she ignored them. At the following session one month later she said she had gone to the doctor's and had had blood tests (CRB2, facing pain, which she had previously avoided). The therapist remarked, "Wow, that used to really scare you" (Rule 3). She often went to the hairdresser's and telephoned acquaintances and old friends. She talked about her depression as a thing of the past, saying that she felt good and that all she needed to do was find people to spend time with and go out with. At the end of this session the therapist decided it was a good time to bring treatment to a close and start follow-up.

Follow-up (Sessions 46 to 48) lasted for 5 months, from month 22 to month 26. In the next session the client talked for the first time about the therapist's office, the decor, and the objects in the office. She also talked about other things such as literature and decoration. She said, "I need to learn more about cultural things" and commented on the books she had bought (CRB2). The therapist felt the conversation was interesting and pleasant, and described this feeling to the patient. She talked about her colleagues and accepted that other people are different and that she needed to adapt. In other words, she seemed to be changing her concept of friendship toward a more flexible view. She remarked, "As soon as I can, I'm moving somewhere else with a transfer to another post or a promotion." She also spoke of her plans for the summer. She asked the therapist to schedule her next appointment for after the summer vacation period, explaining that she felt really well. She remarked, "Before my self-esteem was in pieces, but now I'm putting it back together again."

The next session was held two and a half months later, after a total of 2 years in therapy. CRB2 appeared, such as describing how she had made new acquaintances and was spending time with them in social activities. She asked, "Remember when I said I had to meet people?" (In other words, without prompting she compared her previous situation with her present condition.) The therapist asked, "How have you changed?" and she answered, "Now I see things in a different way. This summer was different from the last few summers." When the therapist asked about her ex-boyfriend, she spoke calmly about the relationship and expressed some rules, "It won't happen to me again. Now I feel sorry for him. I was wrong, I locked myself up inside him, and that's something you shouldn't do. Each person has to live their life." The therapist asked what she had learned from therapy (a question intended to evoke CRB, according to Kohlenberg and Tsai, 1995), and the client responded, "You have to take things in life without getting upset over them. It's me who has to live my life. You shouldn't brood over things and overanalyze them. You shouldn't spend all day thinking to yourself how lonely you are." 
In the final session ( 2 months later, after 26 months of therapy) the client mentioned that she had gained more weight thanks to the fact that she felt calmer. When asked about her colleagues at work, she said they left her alone. During this session she remained calm and pleasant to talk to (CRB2). She was getting along well with her family at home. She made more realistic plans. At the end of this session the possibility of terminating follow-up was raised. The last exchange with the patient, when follow-up was concluded (Kohlenberg and Tsai, 1995), illustrates an example of Rule 5.

T: Do you think you need to come for any more sessions?

C: I don't think so. But I thought you'd tell me when it was okay to stop.

$\mathrm{T}$ : Is there anything else I can help you with?

C: It's me who has to help myself. I can't complain about my life. Other people are worse off.

T: Are you happy?

C: Well, as happy as anybody is. Life has its worries too, and you just have to get over them.

T: What might get you depressed now?

C: Right now, I don't know, but I've learned something: you have to keep fighting.

$\mathrm{T}$ : You'll lose family members and friends-will that get you depressed?

C: I don't think so. I'll have to keep fighting.

These remarks reflected more positive CRB3, and showed that the patient accepted that painful things happen in life, and that she had made a commitment to fight to deal with them.

\section{D) Telephone follow-up}

One year and three months after the final session the patient was contacted by phone. She said she felt well. She had the same job but planned to apply for promotion. She got along better with her colleagues and spoke to them in the office, but had no social relations with them outside working hours. During the previous summer she had gone to the beach on vacation for a few days with some friends and had gone swimming. (She had previously avoided wearing a bathing suit.) She went out on weekends with female and male friends. Her relations with her family were better. The client asked the therapist about his own family for the first time. She remarked that she had had a conflict with some friends and said she had dealt with it. She felt she needed no further help.

\section{RESULTS AND CONCLUSIONS}

An acceptance-based psychotherapeutic procedure such as FAP was useful in treating a depressive disorder of the characteristics seen in this patient. The results were maintained for a period of one year and three months. More importantly, during the follow-up period the client adjusted to the values and changes that therapy had generated.

Intervention took place in three phases, as proposed by Kohlenberg and Tsai (1995). During the initial phase CRB1 were frequent. Although all such behaviors were frequent, treatment centered mainly on the client's resistance to accepting her situation and herself, her complaints about what had happened, her apathy and reluctance to make new social contacts. As the therapist used shaping, leading the client to describe the experiences she avoided and to give her explanation of the facts, the frequency of CRB began to change, with an increase in CRB2. We believe three key moments can be identified in the patient's course during this phase. The first was when shaping was used to help her to face her new social relations (attending a wedding). The second was when she showed aggressive behavior during a session (after being asked if she had heard from her ex-boyfriend). The third occurred during Session 17, when she admitted she had been abused and that the relationship had deteriorated badly. 
During the intermediate phase new CRB1 appeared. The client began to have problems in her relations with others, and began to complain about her job and the people she worked with. At first the complaints were frequent and recurrent, and we feel they formed part of the same response class as in the preceding phase. One of the most notable moments during the intermediate phase was the positive change seen during Session 31, when she recognized that she was making progress, expressed more appropriate rules, and began to change her concept of happiness to make it more consistent with her situation. It was at this time that she realized she could be happy without getting married and having children. However, some backsliding was seen in the following session. Complaining became more frequent again, problems in her relations with others worsened, and in particular, she became resistant to talking about these problems and avoided mentioning what had happened with other people and at work. These difficulties with her social relations also appeared during the sessions, as for example when she arrived late for an appointment and blamed the delay on her emotional problems. In addition, her conversations became repetitive and tedious even for the therapist. During these sessions the therapist considered changing the therapeutic strategy to favor conversations about alternative topics by using natural reinforcement differentially. After this change in strategy, complaining disappeared, the client's social relations and desire to meet new people increased, she made new plans for the future, and became more forthcoming about explaining about conflicts she had experienced and about her future plans.

During the final phase complaining became less frequent and CRB2 became more frequent. She maintained good social relations, accepted other people and made plans. Her conversation became more varied and pleasant, her self-concept improved and she gained weight. There were also improvements in CRB3: she accepted her past and the problems she had had in life. In the follow-up phone conversation one year and three months later, the client continued to adjust to the values that had arisen during therapy and continued to be more accepting of others.

The long duration of the intervention may have been due to the severity of the client's problem. For persons who have received abuse, have been socially isolated and who have few coping skills when they seek professional help, interventions may not be as simple or as brief as for other persons.

Depression is a complex problem that is hard to treat. The patient we describe in this report had a limited social repertoire. Patients who are depressed seem to have deficient social skills, and this in turn makes their social relations more likely to fail. According to Biglan (1991) a low level of social reinforcement is crucial to the onset and maintenance of depression. We feel that an intervention based on in-vivo, face-to-face work with the client during sessions is effective in cases such as that described here, when the client shows strong resistance to change. Like Korner, Kohlenberg and Parker (1996), we do not claim that other types of intervention (counseling, homework, cognitive therapy, training in social skills, etc.) would be ineffective. We share the view of Friman, Hayes and Wilson (1998), who note that interventions in vivo are more potent and yield better results than indirect or contrived interventions.

Our functional analysis of the patient's problem was based on models proposed by Dougher and Hackbert (1994), Kohlenberg, Tsai and Kohlenberg (1996), and Naugle and Follette (1998). Our functional analysis made it possible to choose appropriate goals for intervention. In view of the results, the choice of clinically relevant behaviors seems to have been appropriate.

The patient's resistance to accepting the facts about her life prevented her from getting over her problems. We feel it was appropriate to chose an acceptance-based procedure for this type of problem. Acceptance-based interventions have been shown to be more effective than rational control in pain tolerance (Hayes, Bissett, Korn, Zettle, Rosenfarb, Cooper, and Grundt, 1999) and chronic pain (Augustson, 1999), and we suspect they may be effective for all types of distress in general. As noted by Cordova and Kohlenberg (1994), FAP promotes acceptance through self-observation (CRB3) and reduces feelings of guilt by evoking emotional responses during the session. We feel that the intervention 
developed for our patient favored acceptance by exposing her to her own emotional responses during the sessions, and by offering her a chance to explain and observe the events that had taken place in her own life. We are convinced that favoring acceptance yields a number of benefits. As argued by Cordova and Kohlenberg (1994), contact is increased with lost reinforcers, potentially more productive actions are increased, and aversive arousal is reduced.

We are aware that clinically relevant behaviors appear more frequently than many therapists believe, and that therapy can be effective only if the therapist is sensitive to these types of behaviors during the session (Rule 1), as described by Kohlenberg and Tsai (1991). Moreover, we feel that the relevance of observing the effect of the therapist's behavior on the client's behavior is one of the most important contributions of this approach to psychotherapy. We suggest that observing the psychologist's behavior may also have benefits in other clinical settings such as interventions for developmental delay, speech therapy and education. In closing, we concur with Pérez Alvarez (1996a) in that the difference between functional analytic psychotherapy and behavior therapy lies in their differing conceptualization of the therapeutic relationship.

\section{REFERENCES}

American Psychiatric Association (1994/1995). DSM-IV. Manual diagnóstico y estadístico de los trastornos mentales. Barcelona: Masson.

Augustson, E.M. (1999). Issues of Acceptance in Chronic Pain Populations. The Behavior Analyst Today, 1.1, 14-17.

Biglan, A. (1991). Distressed behavior and its context. The Behavior Analyst, 13, 157-169

Bolling, M.Y.; Kohlenberg, R.J. and Parker, C.R. (1999). Behavior Analysis and Depression. In M.J. Dougher (Ed.). Clinical Behavior Analysis. Reno: Context Press.

Cordova, J.V. and Koerner; K. (1993). Persuasion criteria in research and practice: gathering more meaningful psychotherapy data. The Behavior Analyst, 16,317-330.

Cordova, J.V. and Kohlenberg; R.J. (1994). Acceptance and the therapeutic relationship. In S.C. Hayes; N.S. Jacobson; V.M. Follette and M.J. Dougher (Eds.). Acceptance and Change: content and context in psychotherapy. Reno: Context Press.

Dougher, M.J. and Hackbert, L. (1994). A behavior-analytic account of depression and a case report using acceptance-based procedures. The Behavior Analyst, 17, 321-334.

Ferro, R. and Valero, L. (1998). Psicoterapias Conductistas: nuevos enfoques clínicos. Psicologemas, 23, 31-62.

Friman, P.C.; Hayes, S.C. and Wilson, K.G. (1998). Why behavior analysts should study emotion: The example of anxiety. Journal of Applied Behavior Analysis, 31, 137-156.

Hayes, S.C.; Bissett, R.T.; Korn, Z.; Zettle, R.D.; Rosenfarb, I.S.; Cooper, L.D. and Grundt, A.M. (1999). The impact of acceptance versus control rationales on pain tolerance. The Psychological Record, 49, 33-48. 
Hayes, S.C.; Kohlenberg, B.S. and Melancon, S.M. (1989). Avoiding and Altering Rule-Control as a Strategy of Clinical Intervention. In S.C. Hayes (Ed.) Rule-Governed Behavior. Cognition, Contingencies, and Instructional Control. New York: Plenum Press. (Pp.: 359-385).

Hayes, S.C.; Strosahl, K.D. and Wilson, K.D. (1999). Acceptance and Commitment Therapy. An Experimental Approach to Behavior Change. New York: Guilford.

Hayes, S.C. and Wilson, K.G. (1993). Some applied implication of a contemporary behavior-analytic account of verbal events. The Behavior Analyst, 16, 283-301.

Hayes, S.C.; Zettle, R.D. and Rosenfarb, I. (1989). Rule-Following. In S.C. Hayes (ed.). Rule-governed behavior. Cognition, contingencies, and instructional control. New York: Plenum Press.

Koerner, K.; Kohlenberg, R.J. and Parker, R. (1996). Diagnosis of Personality Disorder: A Radical Behavioral alternative. Journal of Consulting and Clinical Psychology, 64, 1169-1176.

Kohlenberg, R.J.; Hayes, S.C. and Tsai, M. (1993). Radical behavioral psychotherapy: Two contemporary examples. Clinical Psychology Review, 13, 579-592.

Kohlenberg, R.J. and Tsai, M. (1991) Functional analytic psychotherapy. Creating intense and curative therapeutic relationships. New York: Plenum Press.

Kohlenberg, R.J. and Tsai, M. (1994a). Improving cognitive therapy for depression with functional analytic psychotherapy: Theory and case study. The Behavior Analyst, 17, 305-319.

Kohlenberg, R.J. and Tsai, M. (1994b) Functional Analytic Psychotherapy: A Radical Behavioral Approach to Treatment and Integration. Journal of Psychotherapy Integration, 4, 174-201.

Kohlenberg, R.J. and Tsai, M. (1995) Functional Analytic Psychotherapy: A behavioral approach to intensive treatment. In W. O'Donohue and L. Krasner (Eds.) Theories of Behavior Therapy. Washington: American Psychological Association.

Kohlenberg, R.J. and Tsai, M. (1998). Healing interpersonal trauma with the intimacy of the relationship. In V.M. Follette; J.I. Ruzek and F.R. Abueg (Eds.). Cognitive-behavioral Therapies for Trauma. New York: Guilford.

Kohlenberg, R.J., Tsai, M. and Kohlenberg, B.S. (1996). Functional Analysis in Behavior Therapy. In M. Hersen; R.M. Eisler and P.M. Miller (Eds.). Progress in Behavior Modification. New York: Brooks/Cole Publishing.

Michael, J. (1993). Establishing operations. The Behavior Analyst, 16, 191-206.

Naugle, A.E. and Follette, W.C. (1998). A Functional Analysis of Trauma Symptoms. In V. M. Follette; J.I. Ruzek and F.R. Abueg (Eds.). Cognitive-Behavioral Therapies for Trauma. New York: Guilford.

Paul, R.H.; Marx, B.P. and Orsillo, S.M. (1999). Acceptance-based psychotherapy in the treatment of an adjudicated exhibitionist: a case example. Behavior Therapy, 30, 149-162.

Pérez Alvarez, M. (1996a). La Psicoterapia desde un punto de vista conductista. Madrid: Biblioteca Nueva. 
Pérez Alvarez, M. (1996b). Tratamientos Psicológicos. Madrid: Ed. Universitas, S.A.

Skinner, B.F. (1957/1981) Conducta Verbal. México: Trillas.

Sundberg, M.L. (1993). The Application of Establishing Operations. The Behavior Analyst, 16, 211-214.

Zettle, R.D. and Young, M.J. (1987). Rule-following and human operant responding: conceptual and methodological consideration. The Analysis of Verbal Behavior, 5, 3-39.

\section{ACKNOWLEDGMENTS}

We thank Professor Marino Pérez Alvarez for his encouragement and support for our work in this area, and K Shashok for translating the article into English.

Send Correspondence to:

Rafael Ferro García

Centro de Psicología C.E.D.I.

Avda Constitución 25

7 Izda, 18014 Granada, Spain

Tel: +34958286650

e-mail: rferro@correo.cop.es

Additional Author Contact Information:

Luis Valero, Depto. Personalidad, Evaluacion y Tratamientos Psicologicos, Facultad de Psicologia, Campus Teatinos 29071 Malaga, Spain, Tel. 952-132531, Fax. 952-131100, E-mail: lvalero@uma.es

Carmen Vives, Departamento de Personalidad, Evaluación y Tratamientos Psicologicos.

Facultad de Psicologia. Universidad de Granada. Campus universitario de La Cartuja s/n, 18071 Granada. Spain.

E-mail: cvives@ugr.es

Based on an article originally published in Spanish in Análisis y Modificación de Conducta (2000), 26, 106, 291-317. We thank the editors and publisher of this journal for permission to publish this English translation. 